\title{
Financial Literacy and Exercise Behavior: Evidence from Japan
}

\author{
Shunsuke Ono, Pattaphol Yuktadatta, Takafumi Taniguchi, Tomoe Iitsuka, Masafumi Noguchi, Sawa Tanaka, \\ Haruka Ito, Kousei Nakamura, Nanako Yasuhara, Chihiro Miyawaki, Katsumi Mikura, \\ Mostafa Saidur Rahim Khan *(1) and Yoshihiko Kadoya (1)
}

Citation: Ono, S.; Yuktadatta, P.;

Taniguchi, T.; Iitsuka, T.; Noguchi, M.;

Tanaka, S.; Ito, H.; Nakamura, K.;

Yasuhara, N.; Miyawaki, C.; et al.

Financial Literacy and Exercise

Behavior: Evidence from Japan.

Sustainability 2021, 13, 4189. https://

doi.org/10.3390/su13084189

Academic Editor: Jacob Arie Jordaan

Received: 16 March 2021

Accepted: 6 April 2021

Published: 9 April 2021

Publisher's Note: MDPI stays neutral with regard to jurisdictional claims in published maps and institutional affiliations.

Copyright: (C) 2021 by the authors Licensee MDPI, Basel, Switzerland. This article is an open access article distributed under the terms and conditions of the Creative Commons Attribution (CC BY) license (https:// creativecommons.org/licenses/by/ $4.0 /)$.
School of Economics, Hiroshima University, Hiroshima 739-8525, Japan; shun526.baseball@gmail.com (S.O.); d206295@hiroshima-u.ac.jp (P.Y.); takafumi.taniguchi13th@gmail.com (T.T.); iitukahome@gmail.com (T.I.); msms0924@icloud.com (M.N.); sawa0430.t@gmail.com (S.T.); haruka.ito826@gmail.com (H.I.); kousein716@icloud.com (K.N.); konana.920@gmail.com (N.Y.); 461287yym@gmail.com (C.M.); katsumix.1019@gmail.com (K.M.); ykadoya@hiroshima-u.ac.jp (Y.K.)

* Correspondence: khan@hiroshima-u.ac.jp

\begin{abstract}
Lack of exercise, which increases the risk of many serious physical and mental illness, has been a common health issue in Japan. Recent studies confirm that financial literacy discourages irrational behavior like gambling and smoking. We therefore investigate how financial literacy, as a rational decision-making instrument, relates to peoples' exercise behavior in Japan. We hypothesize that financial literacy encourages people to exercise regularly. Using Osaka University's Preference Parameters Study (PPS) for 2010, we categorized respondents into two groups: those who exercise regularly or at least once a week and those who do not. Our probit estimation results show that financial literacy is positively related with exercise behavior, meaning that financially literate people are more likely to exercise regularly. As the COVID-19 health pandemic seems to exacerbate peoples' physical inactivity, the results of our study show an alternative approach to encourage exercise. We therefore recommend that governments implement a financial literacy improvement policy to alleviate the lack of exercise.
\end{abstract}

Keywords: exercise; financial literacy; rationality; Japan

\section{Introduction}

The World Health Organization [1] states that physical inactivity is one of the world's leading health issues. People with an inactive lifestyle are at risk of developing serious physical health conditions [2] and mental illnesses [1,3]. Physical inactivity also burdens the global healthcare system directly and leads to lower productivity in the economy [4]. Thus, governments and health organizations have been advocating exercise to promote the tremendous individual and societal benefits. Empirically, people who exercise regularly are more likely to delay the development of severe physical health problems $[3,5,6]$ improve their physical health [7,8], and recover from mental health problems [6,9-13]. Some studies also suggest that exercise can prolong life expectancy $[14,15]$, while in Japan, Monma et al. [16] found a positive association between a prefecture's healthy life expectancy and the ratio of middle-aged male exercisers. Because of these benefits, exercisers are less likely to suffer from absenteeism and presenteeism and become more productive [17]. Consequently, an increase in physical activity such as regular exercise can increase global GDP by 0.25 to 0.36 percent [17]. Thus, broadly, exercise is a key issue to ensure sustainable development of a country.

Many national and international health policies focus on exercise as a means to promote physical activity. The Japanese government introduced a health policy in 1999 called "Health Japan 21," which aims to reduce lifestyle-related diseases [18]. The Japanese government set a target for the proportion of exercisers aged 20-64 years at 36\% for men and $33 \%$ for women and $58 \%$ for older men and $48 \%$ for older women [19]. Regrettably, the government did not achieve these goals. According to the Ministry of Health, Labor 
and Welfare (MHLW), only $21.6 \%$ of men and $16.6 \%$ of women aged $20-64$ years exercise regularly, while only $42.9 \%$ and $36.5 \%$ older men and older women exercise regularly, respectively [19]. The MHLW reports that the trend of regular exercise among men stagnated for a decade and the trend among women declined considerably [19]. Furthermore, the current measures to curb the COVID-19 pandemic, such as work from home and social distancing, may disrupt exercise routines [20]. Ultimately, lack of exercise may become more severe in Japan [21].

In this study, we investigated lack of exercise from the viewpoint of financial literacy as a proxy for rational decision making. Financial literacy empowers people with the knowledge on financial issues such as compounding, inflation, risk diversification and others, which help them to make better financial decisions. Moreover, financial literacy improves peoples' understanding on the value of information, leading them to have more cognitive ability and rationality. In several related papers, Watanapongvanich et al. [22-24] argued that rationality proxied by financial literacy tends to reduce peoples' involvement in risky health behavior such as smoking and gambling. Some studies also found an association between financial literacy and improved cognitive ability [25], while others found an association between financial illiteracy and limited cognitive ability [26-28]. Hence, people with a high level of financial literacy tend to have better cognitive ability, which is likely to make them more rational. Previous studies also provide evidence on how financial literacy contributes to rational economic behavior [29-40]. People with good financial literacy are more likely to have diverse investments [33,41], prepare for retirement $[29,30,35,36,39,42]$, and make reasonable healthcare decisions [43]. These previous studies provide clear evidence of the role of financial literacy in enhancing cognitive ability and the ability to make rational economic and health decisions.

This study aims to examine the association between financial literacy and exercise behavior among Japanese people. We hypothesize that financial literacy enhances the likelihood that a person exercises regularly. Regular exercise could be perceived as a health investment, according to Grossman's health capital model [44,45]; hence, this study adopts the view that regular exercise is a rational behavior. We argue that financially literate people, being able to make rational decisions, would practice rational health behavior like exercising regularly. Our study makes significant contributions to the existing literature in at least two ways. First, to the best of our knowledge, this is the first study that examines the relationship between exercise and financial literacy. We provide evidence that financially literate people, as rational decision makers, are more likely to exhibit positive health behavior like exercising regularly. Second, the rationality explanation of the lack of exercise among Japanese people provides an opportunity to observe a predominant health issue from a new perspective.

The remainder of this paper proceeds as follows. In the next section, we describe the data and methodology. In Sections 3 and 4, we present and discuss the empirical results. Section 5 offers our conclusions.

\section{Data and Methods}

\subsection{Data}

We used data from the Preference Parameters Study (PPS), an annual panel survey conducted by Osaka University's Institute of Social and Economic Research. This database contains information on the Japanese sample's socioeconomic status and preferences. We used data from the 2010 survey because this wave has information on the respondent's choice to exercise and level of financial literacy. The survey has 5386 responses, of which we excluded 1675 responses, because some respondents did not provide information about their exercise habits or financial literacy. Thus, our sample comprises 3711 responses, or roughly $69 \%$ of the total sample. 


\subsection{Variables}

Our dependent variable, "regular exercise," is based on the PPS's multiple-choice question "Do you exercise?" Respondents can answer 1 for exercise almost every day, 2 for exercise 2 to 4 times a week or so, 3 for exercise once a week or so, 4 for exercise once a month or so, and 5 for hardly exercise. As our hypothesis is that financial literacy encourages people to exercise regularly, we grouped these responses into a binary scale. Because engaging in high-intensity exercise only once or twice per week reduces mortality [46], we categorized respondents who answered 1-3 as regular exercisers and those who answered 4 or 5 as non-regular exercisers, where the variable "regular exercise" equals one in the former case and zero in the latter case.

Our main explanatory variable is financial literacy. We use the three questions proposed by Lusardi and Mitchell [47] to measure a respondent's financial literacy level due to their simplicity and empirical support. These questions measure a respondent's knowledge of compound interest, inflation, and risk diversification. Studies such as [22-24,34,48-55] adopted these three questions, which are as follows:

1. Suppose you had $10,000 \mathrm{JPY}$ in a savings account and the interest rate is $2 \%$ per year and you never withdraw money or interest payments. After 5 years, how much would you have in this account in total?

- More than $¥ 10,200$ (correct answer)

- Exactly $¥ 10,200$

- Do not know

- Refuse to answer

2. Imagine that the interest rate on your savings account is $1 \%$ per year and inflation is $2 \%$ per year. After 1 year, how much would you be able to buy with the money in this account?

- More than today

- Exactly the same

- Less than today (correct answer)

- Do not know

- Refuse to answer

3. Please indicate whether the following statement is true or false. "Buying a company stock usually provides a safer return than a stock mutual fund."

- True

- False (correct answer)

- Do not know

- Refuse to answer

According to Lusardi and Mitchell [47], respondents who can answer questions a and $\mathrm{b}$ correctly seem to have essential economic and mathematic knowledge, while those who can answer question c correctly tend to have the necessary knowledge to make sound investment decisions [47]. Given this argument, we follow [22-24] and assign one point to each correct answer and zero point to each incorrect answer. Then, we find the normal average score to create the literacy variable.

In line with prior studies on the relationship between financial literacy and risky health behavior [22-24], we control demographic and socioeconomic effects such as gender, age, education status, marital status, household financial status, number of household members, and employment status; behavioral effect such as myopic view of the future, level of risk preference, current level of happiness, and anxiety about health; and risky health behavior such as drinking, smoking, and gambling. Table 1 provides the description for all the variables. 
Table 1. Variable definitions.

\begin{tabular}{|c|c|}
\hline Variable & Definition \\
\hline Regular exerciser & $\begin{array}{l}\text { Binary variable: } 1=\text { regular exercise (exercise once } \\
\text { a week or more) and } 0=\text { otherwise }\end{array}$ \\
\hline Financial literacy & $\begin{array}{l}\text { Continuous variable: number of correct answers } \\
\text { from the three financial literacy questions }\end{array}$ \\
\hline Male & Binary variable: $1=$ male and $0=$ female \\
\hline Age & Respondent's age \\
\hline Age squared & Age squared \\
\hline University degree & $\begin{array}{l}\text { Binary variable: } 1=\text { obtained university degree } \\
\text { and zero otherwise }\end{array}$ \\
\hline Marriage & Binary variable: $1=$ married and $0=$ otherwise \\
\hline Divorce & $\begin{array}{l}\text { Binary variable: } 1=\text { divorced or separated and } \\
\text { zero otherwise }\end{array}$ \\
\hline Household size & $\begin{array}{l}\text { Continuous variable: number of people currently } \\
\text { living in the household }\end{array}$ \\
\hline Children & $\begin{array}{l}\text { Binary variable: } 1=\text { have child / children and zero } \\
\text { otherwise }\end{array}$ \\
\hline Unemployed & $\begin{array}{l}\text { Binary variable: } 1=\text { respondent is unemployed } \\
\text { and zero otherwise }\end{array}$ \\
\hline Household income & $\begin{array}{l}\text { Continuous variable: annual earned income of the } \\
\text { entire household before taxes and with bonuses in } \\
2009 \text { (unit: JPY) }\end{array}$ \\
\hline Log of household income & Log (household income) \\
\hline Household assets & $\begin{array}{l}\text { Continuous variable: balance of financial assets } \\
\text { (savings, stock, insurance, etc.) of the entire } \\
\text { household (unit: JPY) }\end{array}$ \\
\hline Log of household assets & Log (household assets) \\
\hline Current smoker & $\begin{array}{l}\text { Binary variable: } 1=\text { current smoker } \\
\text { (sometimes-more than two packs a day) and } 0= \\
\text { non-smokers (do not smoke at all, quit, or hardly } \\
\text { smoke) }\end{array}$ \\
\hline Current drinker & $\begin{array}{l}\text { Binary variable: } 1 \text { = current drinker (drink } \\
\text { sometimes-five cans of beer daily) and } 0 \text { otherwise }\end{array}$ \\
\hline Frequent gambler & $\begin{array}{l}\text { Binary variable: } 1=\text { frequent gambler (gamble } \\
\text { once a week or more) and } 0 \text { otherwise }\end{array}$ \\
\hline Myopic view of the future & $\begin{array}{l}\text { Binary variable: } 1 \text { = agree and completely agree } \\
\text { with the statement, "Since the future is uncertain, } \\
\text { it is a waste to think about it" and } 0 \text { otherwise }\end{array}$ \\
\hline Level of risk preference & $\begin{array}{l}\text { Continuous variable: percentage score from the } \\
\text { question, "Usually, when you go outdoors, how } \\
\text { high does the probability of rain have to be before } \\
\text { you take an umbrella?" }\end{array}$ \\
\hline Current level of happiness & $\begin{array}{l}\text { Continuous variable: percentage score from the } \\
\text { question "Overall, how happy would you say you } \\
\text { are currently?" }\end{array}$ \\
\hline Anxiety about health & $\begin{array}{l}\text { Binary variable: } 1 \text { = agree and completely agree } \\
\text { with the } \\
\text { statement, "I have anxieties about my health" and } \\
0 \text { otherwise }\end{array}$ \\
\hline
\end{tabular}




\subsection{Descriptive Statistics}

According to the descriptive statistics in Table 2, almost half of the respondents $(49.29 \%)$ are men. The average respondent is 49.8 years old and lives in a household of 3.52 people. The majority of the respondents are married $(82.22 \%)$ and have children $(84.42 \%)$, whereas a small proportion are divorced $(3.48 \%)$ or unemployed $(2.4 \%)$. The average household has an annual income equivalent to 6.48 million yen and holds assets worth 13.1 million yen. Roughly $27 \%$ of the respondents received a university degree. The average financial literacy score is 0.59 . In term of the perception variables, $14.63 \%$ of respondents have a myopic view of the future and $41.98 \%$ have anxiety about their health. Furthermore, the respondent's happiness level is $64.7 \%$ on average, and the level of risk preference is $49.08 \%$. For the risky health behavior variables, approximately half of the respondents are current alcohol drinkers, whereas a minority of the respondents are regular exercisers $(37.08 \%)$, current smokers $(24.25 \%)$, or frequent gamblers $(9.38 \%)$.

Table 2. Descriptive statistics.

\begin{tabular}{|c|c|c|c|c|}
\hline Variable & Mean & $\begin{array}{c}\text { Standard } \\
\text { Deviation (SD) }\end{array}$ & Min & Max \\
\hline Regular exerciser & 0.3708 & 0.4831 & 0 & 1 \\
\hline Financial literacy & 0.5911 & 0.3434 & 0 & 1 \\
\hline Male & 0.4929 & 0.5000 & 0 & 1 \\
\hline Age & 49.8041 & 12.6148 & 20 & 76 \\
\hline Age squared & 2639.5380 & 1240.2330 & 400 & 5776 \\
\hline University degree & 0.2700 & 0.4440 & 0 & 1 \\
\hline Marriage & 0.8222 & 0.3824 & 0 & 1 \\
\hline Divorce & 0.0348 & 0.1832 & 0 & 1 \\
\hline Household size & 3.5185 & 1.4354 & 1 & 10 \\
\hline Children & 0.8442 & 0.3627 & 0 & 1 \\
\hline Unemployed & 0.0240 & 0.1530 & 0 & 1 \\
\hline Household income & $6,486,661$ & $3,783,265$ & $1,000,000$ & $20,000,000$ \\
\hline Log of household income & 15.5119 & 0.6147 & 13.8155 & 16.8112 \\
\hline Household assets & $13,100,000$ & $17,600,000$ & $2,500,000$ & $100,000,000$ \\
\hline Log of household assets & 15.8055 & 1.0130 & 14.7318 & 18.4207 \\
\hline Current smoker & 0.2425 & 0.4287 & 0 & 1 \\
\hline Current drinker & 0.5416 & 0.4983 & 0 & 1 \\
\hline Frequent gambler & 0.0938 & 0.2916 & 0 & 1 \\
\hline Myopic view of the future & 0.1463 & 0.3535 & 0 & 1 \\
\hline Level of risk preference & 0.4909 & 0.1891 & 0 & 1 \\
\hline Current level of happiness & 0.6470 & 0.1825 & 0 & 1 \\
\hline Anxiety about health & 0.4198 & 0.4936 & 0 & 1 \\
\hline Observations & & 3711 & & \\
\hline
\end{tabular}

Tables 3-5 summarize the distribution for regular exercise by age group, demographic characteristics, and behaviors, respectively. Table 3 shows a significant difference in exercise behavior by age group. Roughly $30 \%$ of those aged 50 or less exercise regularly. Simultaneously, the proportion of exercisers tends to increase with age; around $40 \%$ of those aged 51 to 60 and approximately a half of the older respondents aged 61 or more exercise routinely. In Table 4, we see heterogeneous exercise behavior by gender and education status. A higher proportion of male respondents exercise frequently $(40.73 \%)$ compared to female respondents $(33.53 \%)$ and a higher proportion of exercisers have university degrees $(41.52 \%)$ than do not $(35.44 \%)$. On the other hand, we see no difference in exercise behavior between unemployed and employed respondents. In Table 5, exercise behavior varies for people with different smoking and drinking behaviors. The proportion of exercisers who smoke $(29.33 \%)$ is substantially lower than the proportion of those who are non-smokers $(39.56 \%)$. The proportion of exercisers who are alcohol drinkers (39.5\%) is significantly higher than the proportion of those who are not drinkers (34.22\%). Lastly, we observe 
no different in exercise behavior between frequent gamblers (35.92\%) and non-frequent gamblers (37.20\%).

Table 3. Distribution of smoking behavior by age group.

\begin{tabular}{|c|c|c|c|c|c|c|}
\hline \multirow{2}{*}{ Exercise Behavior } & \multicolumn{5}{|c|}{ Age } & \multirow{2}{*}{ Total } \\
\hline & $\leq \mathbf{3 0}$ & $31-40$ & $41-50$ & $51-60$ & $\geq 61$ & \\
\hline \multirow[t]{2}{*}{ Exercise once a week or more } & 83 & 200 & 293 & 363 & 437 & 1376 \\
\hline & $30.40 \%$ & $28.99 \%$ & $31.57 \%$ & $37.58 \%$ & $51.17 \%$ & $37.08 \%$ \\
\hline \multirow[t]{2}{*}{ Otherwise } & 190 & 490 & 635 & 603 & 417 & 2335 \\
\hline & $69.60 \%$ & $71.01 \%$ & $68.43 \%$ & $62.42 \%$ & $48.83 \%$ & $62.92 \%$ \\
\hline \multirow[t]{2}{*}{ Total } & 273 & 690 & 928 & 966 & 854 & 3711 \\
\hline & $100 \%$ & $100 \%$ & $100 \%$ & $100 \%$ & $100 \%$ & $100 \%$ \\
\hline Mean difference & & & $=28.15$ * & & & \\
\hline
\end{tabular}

Note: ${ }^{* *} p<0.01$.

Table 4. Distribution of smoking behavior by demographic characteristic.

\begin{tabular}{|c|c|c|c|c|c|c|c|}
\hline \multirow[b]{2}{*}{ Exercise Behavior } & \multicolumn{2}{|c|}{ Gender } & \multicolumn{2}{|c|}{ Education } & \multicolumn{2}{|c|}{ Unemployed } & \multirow[b]{2}{*}{ Total } \\
\hline & Female & Male & $\begin{array}{l}\text { Lower than } \\
\text { University } \\
\text { Degree }\end{array}$ & $\begin{array}{l}\text { University } \\
\text { Degree } \\
\text { and Higher }\end{array}$ & No & Yes & \\
\hline \multirow[t]{2}{*}{ Exercise once a week or more } & 631 & 745 & 960 & 416 & 1346 & 30 & 1376 \\
\hline & $33.53 \%$ & $40.73 \%$ & $35.44 \%$ & $41.52 \%$ & $37.16 \%$ & $33.71 \%$ & $37.08 \%$ \\
\hline \multirow[t]{2}{*}{ Otherwise } & 1251 & 1084 & 1749 & 586 & 2276 & 59 & 2335 \\
\hline & $66.47 \%$ & $59.27 \%$ & $64.56 \%$ & $58.48 \%$ & $62.84 \%$ & $66.29 \%$ & $62.92 \%$ \\
\hline \multirow[t]{2}{*}{ Total } & 1882 & 1829 & 2709 & 1002 & 3622 & 89 & 3711 \\
\hline & $100 \%$ & $100 \%$ & $100 \%$ & $100 \%$ & $100 \%$ & $100 \%$ & $100 \%$ \\
\hline Mean difference & \multicolumn{2}{|c|}{$t=-4.5541 * * *$} & \multicolumn{2}{|c|}{$t=-3.4085 * * *$} & \multicolumn{2}{|c|}{$t=0.6663$} & \\
\hline
\end{tabular}

Table 5. Distribution of smoking behavior by other risky behaviors.

\begin{tabular}{|c|c|c|c|c|c|c|c|}
\hline \multirow{2}{*}{ Exercise Behavior } & \multicolumn{2}{|c|}{ Regular Smoker } & \multicolumn{2}{|c|}{ Current Drinker } & \multicolumn{2}{|c|}{ Frequent Gambler } & \multirow{2}{*}{ Total } \\
\hline & No & Yes & No & Yes & No & Yes & \\
\hline \multirow[t]{2}{*}{ Exercise once a week or more } & 1112 & 264 & 582 & 794 & 1251 & 125 & 1376 \\
\hline & $39.56 \%$ & $29.33 \%$ & $34.22 \%$ & $39.50 \%$ & $37.20 \%$ & $35.92 \%$ & $37.08 \%$ \\
\hline \multirow[t]{2}{*}{ Otherwise } & 1699 & 636 & 1119 & 1216 & 2112 & 223 & 2335 \\
\hline & $60.44 \%$ & $70.67 \%$ & $65.78 \%$ & $60.50 \%$ & $62.80 \%$ & $64.08 \%$ & $62.92 \%$ \\
\hline \multirow[t]{2}{*}{ Total } & 2811 & 900 & 1701 & 2010 & 3363 & 348 & 3711 \\
\hline & $100 \%$ & $100 \%$ & $100 \%$ & $100 \%$ & $100 \%$ & $100 \%$ & $100 \%$ \\
\hline Mean difference & \multicolumn{2}{|c|}{$t=5.5489 * * *$} & \multicolumn{2}{|c|}{$t=-3.3267^{* * *}$} & \multicolumn{2}{|c|}{$t=0.4703$} & \\
\hline
\end{tabular}

Note: ${ }^{* * *} p<0.01$.

\subsection{Methodology}

Since our dependent variable regular exerciser is a binary variable, we performed a probit regression to test our hypothesis. We estimate the following equation:

$$
\mathrm{Y}_{\mathrm{i}}=\mathrm{f}\left(\mathrm{FL}_{\mathrm{i}}, \mathrm{X}_{\mathrm{i}}, \varepsilon_{\mathrm{i}}\right) \text {, }
$$

where $Y_{i}$ represents the $i$ th respondent's exercise behavior (respondent exercises at least once a week or otherwise), FL is the average financial literacy score, $\mathrm{X}$ is a vector of the respondent's characteristics, and $\varepsilon$ is the error term.

Watanapongvanich et al. [23] suggested that financial literacy can be highly correlated with household asset value and education variables like a university degree. Our results may 
therefore suffer from a multicollinearity problem. Following Watanapongvanich et al. [23], we performed the variance inflation factor (VIF) test (available upon request) and find that multicollinearity is insignificant in all models (i.e., our VIF is below 10).

Our model specifications are the following.

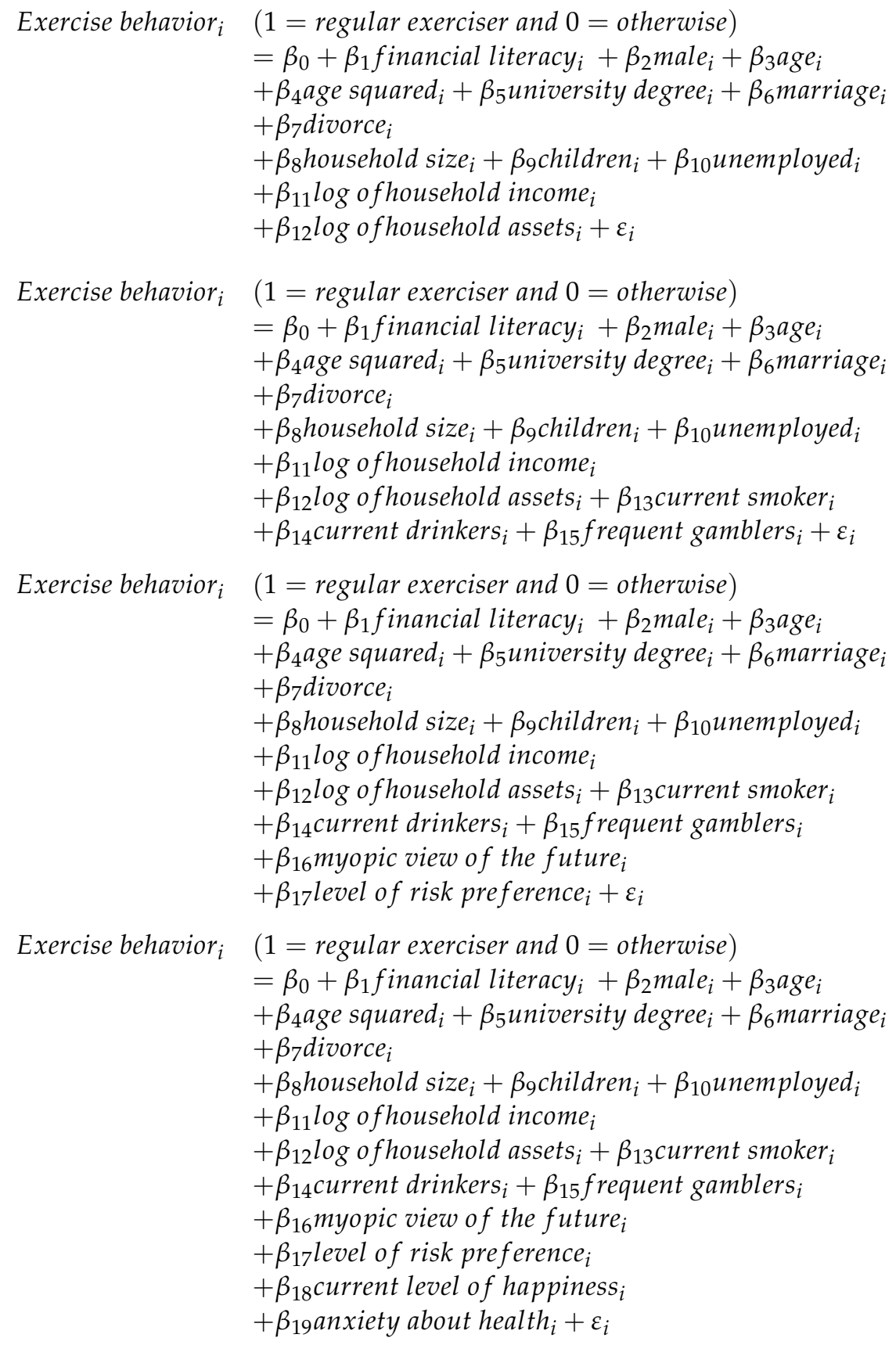

\section{Results}

In Table 6, the first column shows estimates for Model 1, which includes the primary explanatory variable and demographic variables. The second column shows estimates for Model 2, which includes the variables in Model 1 as well as the behavior variables. The third column reports the estimates for Model 3, which includes additional variables like myopic view of the future and risk preference level. Lastly, the fourth column shows the estimates for Model 4, which includes additional variables like the current level of happiness and anxiety about health. 
Table 6. Probit model regression results, financial literacy as the main explanatory variable.

\begin{tabular}{|c|c|c|c|c|}
\hline \multirow{2}{*}{ Variable } & \multicolumn{4}{|c|}{ Dependent Variable: Regular Exerciser } \\
\hline & Model 1 & Model 2 & Model 3 & Model 4 \\
\hline \multirow[t]{2}{*}{ Financial literacy } & $0.181^{* * *}$ & $0.165^{* *}$ & $0.158^{* *}$ & $0.145^{* *}$ \\
\hline & $(0.0682)$ & $(0.0686)$ & $(0.0688)$ & $(0.0693)$ \\
\hline \multirow[t]{2}{*}{ Male } & $0.140 * * *$ & $0.179 * * *$ & $0.182 * * *$ & $0.205^{* * *}$ \\
\hline & $(0.0450)$ & $(0.0501)$ & $(0.0502)$ & $(0.0505)$ \\
\hline \multirow[t]{2}{*}{ Age } & $-0.0475^{* * *}$ & $-0.0436^{* * *}$ & $-0.0441^{* * *}$ & $-0.0367^{* * *}$ \\
\hline & $(0.0132)$ & (0.0133) & $(0.0133)$ & (0.0135) \\
\hline \multirow[t]{2}{*}{ Age squared } & $0.000587^{* * *}$ & $0.000541^{* * *}$ & $0.000545^{* * *}$ & $0.000490^{* * *}$ \\
\hline & $(0.000133)$ & $(0.000134)$ & $(0.000134)$ & $(0.000135)$ \\
\hline \multirow[t]{2}{*}{ University degree } & $0.102 *$ & 0.0735 & 0.0673 & 0.0484 \\
\hline & $(0.0523)$ & $(0.0527)$ & $(0.0529)$ & $(0.0531)$ \\
\hline \multirow[t]{2}{*}{ Marriage } & 0.143 & 0.132 & 0.133 & 0.0663 \\
\hline & $(0.0882)$ & $(0.0888)$ & $(0.0887)$ & $(0.0898)$ \\
\hline \multirow[t]{2}{*}{ Divorce } & 0.0996 & 0.122 & 0.128 & 0.103 \\
\hline & $(0.142)$ & $(0.142)$ & $(0.142)$ & $(0.143)$ \\
\hline \multirow[t]{2}{*}{ Household size } & $-0.0553^{* * *}$ & $-0.0574^{* * *}$ & $-0.0569^{* * *}$ & $-0.0499^{* * *}$ \\
\hline & $(0.0180)$ & $(0.0182)$ & $(0.0182)$ & $(0.0183)$ \\
\hline \multirow[t]{2}{*}{ Children } & -0.0290 & -0.0254 & -0.0291 & -0.0497 \\
\hline & $(0.0885)$ & $(0.0893)$ & $(0.0893)$ & $(0.0897)$ \\
\hline \multirow[t]{2}{*}{ Unemployed } & 0.0374 & 0.0440 & 0.0381 & 0.107 \\
\hline & $(0.144)$ & $(0.144)$ & $(0.144)$ & $(0.146)$ \\
\hline \multirow[t]{2}{*}{ Log of household income } & 0.0647 & 0.0515 & 0.0510 & 0.0108 \\
\hline & $(0.0417)$ & $(0.0418)$ & $(0.0419)$ & $(0.0426)$ \\
\hline \multirow[t]{2}{*}{ Log of household assets } & $0.137^{* * *}$ & $0.135^{* * *}$ & $0.133^{* * *}$ & $0.118^{* * *}$ \\
\hline & $(0.0241)$ & $(0.0243)$ & $(0.0243)$ & $(0.0245)$ \\
\hline \multirow[t]{2}{*}{ Current smoker } & & $-0.289 * * *$ & $-0.282^{* * *}$ & $-0.258^{* * *}$ \\
\hline & & $(0.0551)$ & $(0.0552)$ & $(0.0555)$ \\
\hline \multirow[t]{2}{*}{ Current drinker } & & $0.134^{* * *}$ & $0.135^{* * *}$ & $0.129^{* * *}$ \\
\hline & & $(0.0461)$ & $(0.0461)$ & $(0.0463)$ \\
\hline \multirow[t]{2}{*}{ Frequent gambler } & & 0.00142 & 0.00771 & 0.0167 \\
\hline & & $(0.0758)$ & $(0.0760)$ & $(0.0758)$ \\
\hline \multirow[t]{2}{*}{ Myopic view of the future } & & & -0.0375 & -0.0193 \\
\hline & & & $(0.0617)$ & $(0.0618)$ \\
\hline \multirow[t]{2}{*}{ Level of risk preference } & & & -0.163 & -0.176 \\
\hline & & & $(0.117)$ & $(0.118)$ \\
\hline \multirow[t]{2}{*}{ Current level of happiness } & & & & $0.740^{* * *}$ \\
\hline & & & & $(0.132)$ \\
\hline \multirow[t]{2}{*}{ Anxiety about health } & & & & -0.0730 \\
\hline & & & & $(0.0448)$ \\
\hline \multirow[t]{2}{*}{ Constant } & $-2.799 * * *$ & $-2.628 * * *$ & $-2.490 * * *$ & $-2.267 * * *$ \\
\hline & $(0.651)$ & $(0.653)$ & $(0.661)$ & $(0.665)$ \\
\hline Observations & 3711 & 3711 & 3711 & 3711 \\
\hline Log likelihood & -2337 & -2320 & -2319 & -2300 \\
\hline $\mathrm{Chi}^{2}$ statistics & 209.4 & 238.4 & 240.5 & 272.8 \\
\hline$p$-value & 0.000 & 0.000 & 0.000 & 0.000 \\
\hline
\end{tabular}

Note: Robust standard errors in parentheses, ${ }^{* * *} p<0.01,{ }^{* *} p<0.05,{ }^{*} p<0.1$.

According to Table 6, the effect of financial literacy on exercise behavior is robust and consistent. We find that financial literacy has a positive and significant impact on regular exercise at the $1 \%$ (Model 1 ) and $5 \%$ levels of significance (Models 2-4). The results indicate that financially literate people are more likely to exercise regularly. The other estimates also indicate consistency and robustness. Regardless of the model specification, the relationship between exercise behavior and demographic variables such as age, gender, and household size are consistent. We find that being male increases the likelihood of regular exercise at the $1 \%$ level of significance, whereas larger household size and older age significantly reduce the likelihood, at the $1 \%$ level of significance. However, the statistically significant age-squared variable indicates a non-linear relationship between age and exercise behavior. 
As for the socioeconomic variables, only the relationship between the log of household assets and exercise is consistent and robust. We find that the log of household assets has a significant positive impact on the likelihood of regular exercise at the $1 \%$ significance level. Having a university degree also has a positive and significant effect on regular exercise at the $10 \%$ level of significance (Model 1); however, its effect is neither robust nor consistent. For the risky health behavior variables, the effect of being a current drinker or current smoker is robust and consistent. We find that current drinkers are more likely to exercise regularly, while smokers are less likely to do so at the $1 \%$ significance level. Lastly, we find that the current level of happiness is positively and significantly related to regular exercise at the $1 \%$ level of significance. Overall, our results are robust and consistent.

\section{Discussion}

The positive and significant results confirm our hypothesis that people with higher financial literacy have an increased tendency to exercise regularly. Prior findings that financial literacy discourages irrational behavior like smoking and gambling [22-24] support our results. Moreover, our finding is consistent with Grossman's Human Capital Model $[44,45]$. Financially literate people or those with good investment knowledge will invest in health by exercising regularly. Due to the consensus that financial literacy encourages people to make reasonable health decisions, policy makers in Japan may consider introducing financial literacy enhancement policies to curb current health issues such as lack of regular exercise.

Among the demographic variables, we find that the effect of gender, age, and marital status are consistent with the results reported in prior studies. Our finding on gender is compatible with other studies [56-59], which confirm the existence of gender gap in exercise. This gap results from the imbalance in autonomous forms of motivation, where women are less likely to have intrinsic regulation, integrated regulation, and identified regulation [58]. Since males and females seem to have different levels of motivation in exercise, policy makers may consider reducing the gender gap by implementing a gender-sensitive policy [58]. For the age variables, we find a non-linear negative relationship, meaning that the likelihood of regular exercise decreases up to a certain age and begins to increase after that. The results are somewhat consistent with the findings of Hickey and Mason [60]. We argue that the negative relationship is a result of functional movement deficiency, which causes difficulty in the daily lives of older people, such as when exercising [8,61-63]. However, the higher likelihood of regular exercise at an older age could be the result of availability of time when people retire from jobs. Since functional strength training helps to reduce the risk of deficiency, policy makers could incorporate functional strength training into their future intervention programs [8]. For the marital status variables, our finding is consistent with Chung et al. and Ruseski et al., who found no association between marital status and exercise [64,65]. Nevertheless, Hallmann et al. [66] suggested that there is no academic consensus in this regard. Other variables like household size and children are also inconsistent with other studies. Although we find a negative impact of household size and insignificant effects of children on the likelihood of exercise, Ruseski et al. [65] reported a negligible household size effect on exercise in Germany. This inconsistency may be due to the sociocultural differences between Japan and other developed countries. Families in the current Japanese aging society may experience caregiver strain, which discourages them from exercising [67]. For the children variable, we find an insignificant effect of children on the likelihood of exercise, which contradicts Ruseski et al. [65]. This insignificant effect may be caused by child age. Studies like Eberth and Smith [68] found that families with children aged two or below are less likely to exercise, whereas families with children aged over two are more likely to exercise. Hence, the effect of children in our sample may offset each other. Nevertheless, data limitations prohibit us from exploring this line of inquiry further at this stage, though future studies may explore such relationships.

Among the socioeconomic variables, our findings on unemployment and assets are consistent with other studies. We find that unemployment has an insignificant effect on 
exercise, similar to [69]. We also find a positive relationship between household assets and exercise, which is consistent with the static labor supply model. We can perceive people with a high level of assets as those with a high level of non-labor income. Therefore, people with a high level of assets have more leisure and exercise more, ceteris paribus. Our finding on assets is also consistent with Chung et al. [64], who find an association between household wealth and physical activity. Our results for socioeconomic variables like university degrees and household income are inconsistent with other studies. For the income variable, while we find an insignificant effect of income on exercise behavior, as in [70,71], Shuval et al. [72] indicated that income level affects physical activity. For the education variable, Huang and Humphreys [73] and Hoekman et al. [74] reported a positive relationship between education level and a physically active lifestyle. However, we find no such relationship. Our finding on university degrees seems to align with [75], in which the effect of education on sports participation in Belgium became less persistent over time, eventually becoming insignificant in 1999 and 2009. Since the PPS collected data on exercise behavior only in 2010, future studies may collect more data and do so more frequently to explore these inconsistent relationships in detail.

Among the risky health behavior variables, we find that smoking decreases the likelihood of regular exercise while drinking alcohol has the opposite effect. The findings are consistent with previous studies on the association between physical activities with smoking and drinking alcohol. Heydari et al. [76] and Kujala et al. [77] found a negative association between smoking and physical activity. Since smoking leads to ineffective oxygen delivery to smokers' muscles, heart, and lung, smokers are more likely to be easily tired and have low physical fitness [78-80]. Therefore, smokers may not be able to exercise properly and give up exercise. On the other hand, as alcohol consumption strongly associates with sport culture and sports events [81] and group drinking activity is perceived as the bonding activity among athletes [82], the positive association between alcohol consumption and exercise seems acceptable. Our findings on the association between alcohol consumption and exercise are also consistent with previous studies [83-85]. However, our finding that frequent gambling does not have a significant relationship with exercise is inconsistent with Håkansson et al. [86], who found a positive association between problem gambling and physical activity. Among the behavioral variables, our finding on the positive association of happiness level with regular exercise is consistent with other studies [87-90]. Intuitively, people with a high level of happiness are more likely to have energy and feel less fatigue than people with depression or a low level of happiness. As a result of higher level of energy and less fatigue, happy people are more likely to exercise regularly. On the other hand, we found an insignificant effect of a myopic view of the future, risk preference, and health anxiety on exercise behavior. These findings are inconsistent with other studies. For the myopic view of future variable, Adams and Nettle [91] and Milfont et al. [92] found a positive relationship between forwardthinking and physical activity. Meanwhile, Hunter et al. [93] found a specific relationship between risk preference and physical activity. Lastly, Lejoyeux et al. [94] and Pugh and Hadjistavropoulos [95] indicated a positive association between health anxiety and exercise. The contradiction between our findings and others may arise from measurement and sample selection difference.

\section{Conclusions}

Recent studies suggest that financial literacy is a rational decision-making instrument that reduces the likelihood that people will engage in risky health behaviors like smoking and gambling [22-24]. These results motivated us to investigate whether financial literacy encourages a positive health behavior like exercising regularly among Japanese people. Based on a sample of 3711 from Osaka University's 2010 PPS, we hypothesize that people with higher financial literacy are more likely to exercise regularly. Our results indicate a positive and significant relationship between financial literacy and regular exercise, supporting our hypothesis. We argue that financially literate people or those with good 
investment knowledge will invest in health by exercising regularly. The findings emphasize the role of financial literacy in improving peoples' rational decision-making capacity, as in previous studies $[23,33,34,37,39,96]$. Moreover, our study shows that respondents who are males, middle-aged, have smaller household size, have higher balance of financial assets, are not current smokers, current drinkers, and are currently happy are more likely to exercise regularly.

Our study has some limitations to consider when interpreting the results. First, we followed the guideline of the MHLW [97] to define regular exerciser as a person who exercises $30 \mathrm{~min}$ or more at a time and does so at least twice a week for at least a year. However, we could not check robustness of the results with alternative definitions of regular exercise such as exercising once or twice in a week for at least 150 min or high intensity exercise once or twice in a week due to limitation of data. Therefore, our study assumes that respondents engage in high-intensity exercise and define exercise accordingly. Moreover, this data limitation may also be the cause of the inconsistency between our findings and others, as mentioned earlier. Future studies may consider collecting more data to explore those relationships in the Japanese context more extensively. Second, our approach to measuring financial literacy is limited to Lusardi and Mitchell's [47] three questions, which we use because they are widely adopted (e.g., [48,50,51,54,55]) and Nicolini and Haupt [98] recently demonstrated that these three questions are still viable. Hence, we argue that our choice to adopt Lusardi and Mitchell's [47] three questions is justified. Nevertheless, few studies questioned the reliability of the measures of financial literacy in predicting financial behavior and economic outcomes $[99,100]$. Third, our study measures variables like a myopic view of the future, risk preference, and health anxiety through a limited number of questions, which may not be sufficient to detect the relationship between these variables and exercise behavior. The variable measurement issues could be responsible for the insignificant and inconsistent results.

Nevertheless, our study provides primary evidence that financial literacy, which enables people to make rational decisions, enhances the likelihood of engaging in rational health behaviors like exercising regularly. The study findings have implications for the ongoing health pandemic as peoples' exercise habits have been affected due to lockdown and other virus controlling measures. Motivating people to do regular exercise when they cannot go outside has become a major challenge. The results of this study provide an opportunity to explain the problem of lack of exercise from a different perspective. The value of exercise, as an investment in health capital, would be better understood when people think rationally. Thus, educating people with the concept of health as a capital goods should be prioritized. We argue that the Japanese government should consider implementing financial literacy programs in light of these findings. Improving financial literacy among the Japanese population may lessen health issues such as a lack of regular exercise. Future studies may consider exploring the design of policies that aim to enhance people's financial literacy effectively and efficiently.

Author Contributions: Conceptualization, S.O., T.T., T.I., M.N., S.T., H.I., K.N., N.Y., C.M., K.M., and Y.K.; methodology, S.O., P.Y., T.T., T.I., M.N., S.T., H.I., K.N., N.Y., C.M., K.M., and Y.K.; software, S.O., P.Y., T.T., T.I., M.N., S.T., H.I., K.N., N.Y., C.M., K.M., and Y.K.; validation, S.O., T.T., T.I., M.N., S.T., H.I., K.N., N.Y., C.M., K.M., and Y.K.; formal analysis, S.O., P.Y., T.T., T.I., M.N., S.T., H.I., K.N., N.Y., C.M., K.M., M.S.R.K., and Y.K.; investigation, S.O., P.Y., T.T., T.I., M.N., S.T., H.I., K.N., N.Y., C.M., K.M., M.S.R.K., and Y.K.; resources, Y.K.; data curation, S.O., P.Y., T.T., T.I., M.N., S.T., H.I., K.N., N.Y., C.M., and K.M.; writing—original draft preparation, S.O., P.Y., T.T., T.I., M.N., S.T., H.I., K.N., N.Y., C.M., K.M., M.S.R.K., and Y.K.; writing-review and editing, S.O., P.Y., M.S.R.K., and Y.K.; visualization, S.O., P.Y., M.S.R.K., and Y.K.; supervision, Y.K.; project administration, Y.K.; funding acquisition, Y.K. and M.S.R.K. All authors have read and agreed to the published version of the manuscript.

Funding: This work is supported by JSPS KAKENHI, grant numbers 19K13739 and 19K13684, and RISTEX, JST. 
Institutional Review Board Statement: The study was conducted according to the guidelines of the Declaration of Helsinki.

Informed Consent Statement: Informed consent was obtained from all subjects involved in this study.

Data Availability Statement: Data is available on request.

Acknowledgments: This research used micro data from the Preference Parameters Study of Osaka University's 21st Century COE Program, "Behavioral Macrodynamics Based on Surveys and Experiments" and its Global COE project, "Human Behavior and Socioeconomic Dynamics." The authors acknowledge the program/project's contributors: Yoshiro Tsutsui, Fumio Ohtake, and Shinsuke Ikeda. We are also grateful for helpful comments from Stella Lartey, Somtip Watanapongvanich, and Pongpat Putthinun.

Conflicts of Interest: The authors declare no conflict of interest. The funders had no role in the study design, data collection and analysis, preparation of the manuscript, or decision to publish.

\section{References}

1. World Health Organization. Physical Activity. 26 November 2020. Available online: https://www.who.int/news-room/factsheets/detail/physical-activity (accessed on 20 February 2021).

2. Centers for Disease Control and Prevention. Lack of Physical Activity ICDC. 25 September 2019. Available online: https: //www.cdc.gov/chronicdisease/resources/publications/factsheets/physical-activity.htm (accessed on 22 February 2021).

3. Booth, F.W.; Roberts, C.K.; Laye, M.J. Lack of Exercise is a Major Cause of Chronic Diseases. Comp. Physiol. 2012, 2, 1143-1211. [CrossRef]

4. Ding, D.; Lawson, K.D.; Kolbe-Alexander, T.L.; Finkelstein, E.A.; Katzmarzyk, P.T.; van Mechelen, W.; Pratt, M. The Economic Burden of Physical Inactivity: A Global Analysis of Major Non-communicable Diseases. Lancet 2016, 388, 1311-1324. [CrossRef]

5. U.S. Department of Health and Human Services. Surgeon General's Report on Physical Activity and Health. JAMA J. Am. Med. Assoc. 1996, 276, 522. [CrossRef]

6. Esch, T.; Stefano, G.B. Endogenous Reward Mechanisms and their Importance in Stress Reduction, Exercise and the Brain. Arch Med. Sci. 2010, 3, 447-455. [CrossRef]

7. Barranco-Ruiz, Y.; Villa-González, E. Choreographic Group-Based Fitness Classes Improve Cardiometabolic Health-Related Anthropometric Indices and Blood Lipids Profile in Overweight Sedentary Women. Sustainability 2021, 13, 972. [CrossRef]

8. Guler, O.; Tuncel, O.; Bianco, A. Effects of Functional Strength Training on functional Movement and Balance in Middle-Aged Adults. Sustainability 2021, 13, 1074. [CrossRef]

9. Dunn, A.L.; Trivedi, M.H.; Kampert, J.B.; Clark, C.G.; Chambliss, H.O. Exercise Treatment for Depression. Am. J. Prev. Med. 2005, 28, 1-8. [CrossRef] [PubMed]

10. Dunn, A.L.; Jewell, J.S. The Effect of Exercise on Mental Health. Curr. Sports Med. Rep. 2010, 9, 202-207. [CrossRef]

11. Helgadóttir, B.; Hallgren, M.; Ekblom, Ö.; Forsell, Y. Training Fast or Slow? Exercise for Depression: A Randomized Controlled Trial. Prev. Med. 2016, 91, 123-131. [CrossRef]

12. Hu, M.X.; Turner, D.; Generaal, E.; Bos, D.; Ikram, M.K.; Ikram, M.A.; Cuijpers, P.; Penninx, B.W.J.H. Exercise Interventions for the Prevention of Depression: A Systematic Review of Meta-Analyses. BMC Pub. Health 2020, 20, 1-20. [CrossRef]

13. Schuch, F.B.; Vancampfort, D.; Firth, J.; Rosenbaum, S.; Ward, P.B.; Silva, E.S.; Hallgren, M.; Ponce De Leon, A.; Dunn, A.L.; Deslandes, A.C.; et al. Physical Activity and Incident Depression: A Meta-Analysis of Prospective Cohort Studies. Am. J. Psych. 2018, 175, 631-648. [CrossRef] [PubMed]

14. Lee, I.-M.; Shiroma, E.J.; Lobelo, F.; Puska, P.; Blair, S.N.; Katzmarzyk, P.T. Effect of Physical Inactivity on Major NonCommunicable Diseases Worldwide: An Analysis of Burden of Disease and Life Expectancy. Lancet 2012, 380, 219-229. [CrossRef]

15. Mandsager, K.; Harb, S.; Cremer, P.; Phelan, D.; Nissen, S.E.; Jaber, W. Association of Cardiorespiratory Fitness with long-Term Mortality among Adults Undergoing Exercise Treadmill Testing. JAMA Netw. Open 2018, 1, e183605. [CrossRef]

16. Monma, T.; Takeda, F.; Noguchi, H.; Takahashi, H.; Watanabe, T.; Tamiya, N. Exercise or Sports in Midlife and Healthy Life Expectancy: An Ecological Study in all Prefectures in Japan. BMC Pub. Health 2019, 19, 1238. [CrossRef] [PubMed]

17. Hafner, M.; Yerushalmi, E.; Phillips, W.D.; Pollard, J.; Deshpande, A.; Whitmore, M.; Millard, F.; Subel, S.; van Stolk, C. The Economic Benefits of a More Physically Active Population: An International Analysis. Santa Monica; RAND Corporation: Santa Monica, CA, USA, 2019.

18. Sakurai, H. Healthy Japan 21. Jpn. Med. Assoc. J. 2003, 46, 47-49.

19. Ministry of Health, Labor, and Welfare. National Health and Nutrition Survey. 2018. Available online: https://www.mhlw.go.jp/ content/10900000/000688863.pdf (accessed on 18 February 2021).

20. Rutkowska, A.; Kacperak, K.; Rutkowski, S.; Cacciante, L.; Kiper, P.; Szczegielniak, J. The Impact of Isolation Due to COVID-19 on Physical Activity Levels in Adult Students. Sustainability 2021, 13, 446. [CrossRef]

21. Mizuno, H. "Koronaka" Toshiteno Undoubusoku (The Lack of Physical Activity in the COVID-19 Situation); Life Design Report, Watching; Dai Ichi Life Research Inc.: Tokyo, Japan, 2020. Available online: http://group.dai-ichi-life.co.jp/dlri/pdf/ldi/2020/wt2005b.pdf (accessed on 12 February 2021). 
22. Watanapongvanich, S.; Binnagan, P.; Putthinun, P.; Khan, M.S.R.; Kadoya, Y. Financial Literacy and Gambling Behavior: Evidence from Japan. J. Gambl. Stud. 2020, 1-21. [CrossRef]

23. Watanapongvanich, S.; Khan, M.S.R.; Putthinun, P.; Ono, S.; Kadoya, Y. Financial Literacy, Financial Education, and Smoking Behavior: Evidence from Japan. Front. Public Health 2021, 8, 1005. [CrossRef]

24. Watanapongvanich, S.; Khan, M.S.R.; Putthinun, P.; Ono, S.; Kadoya, Y. Financial Literacy and Gambling Behavior in the United States. 2021. Available online: https:/ / papers.ssrn.com/sol3/papers.cfm?abstract_id=3778466 (accessed on 25 February 2021).

25. Lusardi, A.; Mitchell, O.S.; Curto, V. Financial Literacy among the Young. J. Consum. Aff. 2010, 44, 358-380. [CrossRef]

26. Christelis, D.; Jappelli, T.; Padula, M. Cognitive Abilities and Portfolio Choice. Eur. Econ. Rev. 2010, 54, 18-38. [CrossRef]

27. Kimball, M.S.; Shumway, T. Investor Sophistication and the Home Bias, Diversification, and Employer Stock Puzzles. SSRN Electron. J. 2010, 1-28. [CrossRef]

28. Van Rooij, M.; Lusardi, A.; Alessie, R. Financial Literacy and Stock Market Participation. J. Financ. Econ. 2011, 101, 449-472. [CrossRef]

29. Alessie, R.; van Rooij, M.; Lusardi, A. Financial Literacy and Retirement Preparation in the Netherlands. J. Pension Econ. Financ. 2011, 10, 527-545. [CrossRef]

30. Boisclair, D.; Lusardi, A.; Michaud, P. Financial Literacy and Retirement Planning in Canada. J. Pension Econ. Financ. 2017, 16, 277-296. [CrossRef]

31. Braunstein, S.; Welch, C. Financial Literacy: An Overview of Practice, Research, and Policy. Fed. Reserv. Bull. 2002, 88, 445-457. [CrossRef]

32. Hastings, J.; Mitchell, O.S. How Financial Literacy and Impatience Shape Retirement Wealth and Investment Behaviors. J. Pension Econ. Financ. 2018, 19, 1-20. [CrossRef]

33. Khan, M.S.R.; Rabbani, N.; Kadoya, Y. Is Financial Literacy Associated with Investment in Financial Markets in the United States? Sustainability 2020, 12, 7370. [CrossRef]

34. Lusardi, A.; Mitchell, O.S. The Economic Importance of Financial Literacy: Theory and Evidence. J. Econ. Lit. 2014, 52, 5-44. [CrossRef]

35. Lusardi, A.; Michaud, P.-C.; Mitchell, O.S. Optimal Financial Knowledge and Saving for Retirement; RAND Working Paper No. WR-905-SSA; RAND Corporation: Santa Monica, CA, USA, 2011.

36. Mandell, L. Financial Literacy of High School Students. In Handbook of Consumer Finance Research; Xiao, J.J., Ed.; Springer: New York, NY, USA, 2008; pp. 163-183.

37. Meier, S.; Sprenger, C. Present-Biased Preferences and Credit Card Borrowing. Am. Econ. J. Appl. Econ. 2010, 2, 193-210. [CrossRef]

38. Willis, L.E. The Financial Education Fallacy. Am. Econ. Rev. 2011, 101, 429-434. [CrossRef]

39. Yoshino, N.; Morgan, P.J.; Trinh, L.Q. Financial Literacy in Japan: Determinants and Impacts; ADBI Working Paper No. 796; Asian Development Bank Institute: Tokyo, Japan, 2017. Available online: https:/ /www.adb.org/publications/financial-literacy-japandeterminants-and-impacts (accessed on 13 February 2021).

40. Swiecka, B.; Yeşildağ, E.; Özen, E.; Grima, S. Financial Literacy: The Case of Poland. Sustainability 2020, 12, 700. [CrossRef]

41. Abreu, M.; Mendes, V. Financial Literacy and Portfolio Diversification. Quant. Financ. 2010, 10, 515-528. [CrossRef]

42. Almenberg, J.; Säve-Söderbergh, J. Financial Literacy and Retirement Planning in Sweden. J. Pension Econ. Financ. 2011, 10, 585-598. [CrossRef]

43. James, B.D.; Boyle, P.A.; Bennett, J.S.; Bennett, D.A. The Impact of Health and Financial Literacy on Decision Making in Community-Based Older Adults. Gerontology 2012, 58, 531-539. [CrossRef]

44. Grossman, M. On the Concept of Health Capital and the Demand for Health. J. Political Econ. 1972, 80, 223-255. [CrossRef]

45. Grossman, M. The Human Capital Model. In Handbook of Health Economics; Culyer, A.J., Newhouse, J.P., Eds.; Elsevier: Amsterdam, The Netherlands, 2007; Volume 1, pp. 347-408. Available online: https:/ / econpapers.repec.org/bookchap/eeeheachp/1-07.htm (accessed on 15 February 2021).

46. O'Donovan, G.; Lee, I.; Hamer, M.; Stamatakis, E. Association of "Weekend Warrior" and Other Leisure Time Physical Activity Patterns with Risks for All-Cause, Cardiovascular Disease, and Cancer Mortality. JAMA Intern. Med. 2017, 177, 335-342. [CrossRef]

47. Lusardi, A.; Mitchell, O.S. Planning and Financial Literacy: How Do Women Fare? Am. Econ. Rev. 2008, 98, 413-417. [CrossRef]

48. Fornero, E.; Monticone, C. Financial Literacy and Pension Plan Participation in Italy. J. Pension Econ. Financ. 2011, 10, 547-564. [CrossRef]

49. Lusardi, A.; Mitchell, O.S. Financial Literacy Around the World: An Overview. J. Pension Econ. Financ. 2011, 10, 497-508. [CrossRef]

50. Kadoya, Y.; Khan, M.S.R. Can Financial Literacy Reduce Anxiety About Life in Old Age? J. Risk Res. 2017, 21, 1533-1550. [CrossRef]

51. Kadoya, Y.; Khan, M.S.R. What Determines Financial Literacy in Japan? J. Pension Econ. Financ. 2019, 19, 353-371. [CrossRef]

52. Kadoya, Y.; Khan, M.S.R.; Hamada, T.; Dominguez, A. Financial Literacy and Anxiety About Life in Old Age: Evidence from the USA. Rev. Econ. Househ. 2018, 16, 859-878. [CrossRef]

53. Kadoya, Y.; Khan, M.S.R.; Oba, H.; Narumoto, J. Factors Affecting Knowledge About the Adult Guardianship and Civil Trust Systems: Evidence from Japan. J. Women Aging 2020, 1-15. [CrossRef]

54. Klapper, L.; Panos, G.A. Financial Literacy and Retirement Planning: The Russian Case. J. Pension Econ. Financ. 2011, 10, 599-618. [CrossRef]

55. Sekita, S. Financial Literacy and Retirement Planning in Japan. J. Pension Econ. Financ. 2011, 10, 637-656. [CrossRef] 
56. Azevedo, M.R.; Araújo, C.L.P.; Reichert, F.F.; Siqueira, F.V.; da Silva, M.C.; Hallal, P.C. Gender Differences in Leisure-Time Physical Activity. Int. J. Public Health 2007, 52, 8-15. [CrossRef] [PubMed]

57. D’Urzo, K.; Johnson, A.; McEachern, B.; McPhee, I.; Brennan, A.; Fenuta, A.; Lau, R.; Shirazipour, C.; Hefnawi, B.; Tomasone, J. Investigating Gender Differences in Physical Activity Behavior and Social Cognitions among First-Year Medical Students. MedEdPublish 2019, 8, 1-12. [CrossRef]

58. Luque-Casado, A.; Mayo, X.; Lavín-Pérez, A.M.; Jiménez, A.; Del Villar, F. Understanding Behavioral Regulation Towards Physical Activity Participation: Do we Need a Paradigm Shift to Close the Gender Gap? Sustainability 2021, 13, 1683. [CrossRef]

59. Trost, S.G.; Pate, R.R.; Sallis, J.F.; Freedson, P.S.; Taylor, W.C.; Dowda, M.; Sirard, J. Age and Gender Differences in Objectively Measured Physical Activity in Youth. Med. Sci. Sports Exerc. 2002, 34, 350-355. [CrossRef]

60. Hickey, M.E.; Mason, S.E. Age and Gender Differences in Participation Rates, Motivators for and Barriers to Exercise. Mod. Psychol. Stud. 2017, 22, 10-19.

61. McLean, R.R.; Shardell, M.D.; Alley, D.E.; Cawthon, P.M.; Fragala, M.S.; Harris, T.B.; Kenny, A.M.; Peters, K.W.; Ferrucci, L.; Guralnik, J.M.; et al. Criteria for Clinically Relevant Weakness and Low Lean Mass and Their Longitudinal Association with Incident Mobility Impairment and Mortality: The Foundation for the National Institutes of Health (FNIH) Sarcopenia Project. J. Gerontol. Ser. A Biomed. Sci. Med Sci. 2014, 69, 576-583. [CrossRef] [PubMed]

62. Papa, E.V.; Dong, X.; Hassan, M. Skeletal Muscle Function Deficits in the Elderly: Current Perspectives on Resistance Training. J. Nat. Sci. 2017, 3, e272. [PubMed]

63. Visser, M.; Goodpaster, B.H.; Kritchevsky, S.B.; Newman, A.B.; Nevitt, M.; Rubin, S.M.; Simonsick, E.M.; Harris, T.B. Muscle Mass, Muscle Strength, and Muscle Fat Infiltration as Predictors of Incident Mobility Limitations in Well-Functioning Older Persons. J. Gerontol. Ser. A Biolmed. Sci. Med. Sci. 2005, 60, 324-333. [CrossRef] [PubMed]

64. Chung, S.; Domino, M.E.; Stearns, S.C.; Popkin, B.M. Retirement and Physical Activity. Am. J. Prev. Med. 2009, 36, 422-428. [CrossRef]

65. Ruseski, J.E.; Humphreys, B.R.; Hallmann, K.; Breuer, C. Family Structure, Time Constraints, and Sport Participation. Eur. Rev. Aging Phys. Act. 2011, 8, 57-66. [CrossRef]

66. Hallmann, K.; Artime, C.M.; Breuer, C.; Dallmeyer, S.; Metz, M. Leisure Participation: Modelling the Decision to Engage in Sports and Culture. J. Cult. Econ. 2016, 41, 467-487. [CrossRef]

67. Lam, J.; Garcia-Roman, J. Eldercare and Time Constraints: Does Access or Utilization of Workplace Leave Matter? Innov. Aging 2017, 1 (Suppl. 1), 31. [CrossRef]

68. Eberth, B.; Smith, M.D. Modelling the Participation Decision and Duration of Sporting Activity in Scotland. Econ. Model. 2010, 27, 822-834. [CrossRef]

69. Gough, M. A Couple-Level Analysis of Participation in Physical Activity During Unemployment. SSM-Pop. Health 2017, 3, 294-304. [CrossRef]

70. Armstrong, S.; Wong, C.A.; Perrin, E.; Page, S.; Sibley, L.; Skinner, A. Association of Physical Activity with Income, Race/Ethnicity, and Sex among Adolescents and Young Adults in the United States. JAMA Pediatr. 2018, 172, 732-740. [CrossRef] [PubMed]

71. Kari, J.T.; Pehkonen, J.; Hirvensalo, M.; Yang, X.; Hutri-Kähönen, N.; Raitakari, O.T.; Tammelin, T.H. Income and Physical Activity among Adults: Evidence from Self-Reported and Pedometer-Based Physical Activity Measurements. PLoS ONE 2015, 10, e0135651. [CrossRef]

72. Shuval, K.; Li, Q.; Gabriel, K.P.; Tchernis, R. Income, Physical Activity, Sedentary Behavior, and the 'Weekend Warrior' among U.S. Adults. Prev. Med. 2017, 103, 91-97. [CrossRef] [PubMed]

73. Huang, H.; Humphreys, B.R. Sports Participation and Happiness: Evidence from US Microdata. J. Econ. Psychol. 2012, 33, 776-793. [CrossRef]

74. Hoekman, R.; Breedveld, K.; Kraaykamp, G. Sport Participation and the Social and Physical Environment: Explaining Differences between Urban and Rural Areas in the Netherlands. Leis. Stud. 2017, 37, 357-370. [CrossRef]

75. Scheerder, J.; Vos, S. Social Stratification in Adults' Sports Participation from a Time-Trend Perspective: Results from a 40-year Household Study. Eur. J. Sport Soc. 2011, 8, 31-44. [CrossRef]

76. Heydari, G.; Hosseini, M.; Yousefifard, M.; Asady, H.; Baikpour, M.; Barat, A. Smoking and Physical Activity in healthy Adults: A Cross-Sectional study in Tehran. Tanaffos 2015, 14, 238-245. [PubMed]

77. Kujala, U.M.; Kaprio, J.; Rose, R.J. Physical Activity in Adolescence and Smoking in Young Adulthood: A Prospective Twin Cohort Study. Addiction 2007, 102, 1151-1157. [CrossRef]

78. National Cancer Institute. How Smoking Affects Your Workout. Available online: https://smokefree.gov/quit-smoking/whyyou-should-quit/how-smoking-affects-your-workout (accessed on 1 April 2021).

79. Conway, T.L.; Cronan, T.A. Smoking, Exercise, and Physical Fitness. Prev. Med. 1992, 21, 723-734. [CrossRef]

80. National Health Service. Quit Smoking. 2018. Available online: https://www.nhs.uk/live-well/quit-smoking/ (accessed on 1 April 2021).

81. El-Sayed, M.S.; Ali, N.; El-Sayed Ali, Z. Interaction between Alcohol and Exercise. Sports Med. 2005, 35, 257-269. [CrossRef]

82. Vella, L.D.; Cameron-Smith, D. Alcohol, Athletic Performance and Recovery. Nutrients 2010, 2, 781-789. [CrossRef]

83. Abrantes, A.M.; Scalco, M.D.; O’Donnell, S.; Minami, H.; Read, J.P. Drinking and Exercise Behaviors among College Students: Between and Within-Person Associations. J. Behav. Med. 2017, 40, 964-977. [CrossRef] 
84. French, M.T.; Popovici, I.; Maclean, J.C. Do Alcohol Consumers Exercise More? Findings from a National Survey. Am. J. Health Promot. 2009, 24, 2-10. [CrossRef] [PubMed]

85. Lisha, N.E.; Martens, M.; Leventhal, A.M. Age and Gender as Moderators of the Relationship between Physical Activity and Alcohol Use. Addict. Behav. 2011, 36, 933-936. [CrossRef] [PubMed]

86. Håkansson, A.; Entezarjou, A.; Kenttä, G.; Fernández-Aranda, F.; Jiménez-Murcia, S.; Gunnarsson, B. Problem Gambling in the Fitness World-A General Population Web Survey. Int. J. Environ. Res. Pub. Health 2020, 17, 1342. [CrossRef] [PubMed]

87. Cheon, H.U. The Structural Relationship between Exercise Frequency, Social Health, and Happiness in Adolescents. Sustainability 2021, 13, 1050. [CrossRef]

88. Kim, E.S.; Kubzansky, L.D.; Soo, J.; Boehm, J.K. Maintaining Healthy Behavior: A Prospective Study of Psychological Well-Being and Physical Activity. Ann. Behav. Med. 2017, 51, 337-347. [CrossRef]

89. Kushlev, K.; Drummond, D.M.; Diener, E. Subjective Well-Being and Health Behaviors in 2.5 Million Americans. App. Psychol. Health Well-Being 2019, 12, 166-187. [CrossRef]

90. You, S.; Shin, K.; Kim, M. Long-Term Effect of Physical Activity on Internalizing and Externalizing Problems and Life Satisfaction. Sustainability 2021, 13, 2322. [CrossRef]

91. Adams, J.; Nettle, D. Time Perspective, Personality and Smoking, Body Mass, and Physical Activity: An Empirical Study. Br. J. Health Psychol. 2009, 14, 83-105. [CrossRef] [PubMed]

92. Milfont, T.L.; Vilar, R.; Araujo, R.C.R.; Stanley, R. Does Promotion Orientation Help Explain Why Future-Orientated People Exercise and Eat Healthy? Front. Psychol. 2017, 8, 1202. [CrossRef]

93. Hunter, R.F.; Tang, J.; Hutchinson, G.; Hutchinson, G.; Chilton, S.; Holmes, D.; Kee, F. Association between Time Preference, Present-Bias and Physical Activity: Implications for Designing Behavior Change Interventions. BMC Pub. Health 2018, 18, 1388. [CrossRef]

94. Lejoyeux, M.; Avril, M.; Richoux, C.; Embouazza, H.; Nivoli, F. Prevalence of Exercise Dependence and Other Behavioral Addictions among Clients of a Parisian Fitness Room. Compr. Psychiatry 2008, 49, 353-358. [CrossRef]

95. Pugh, N.E.; Hadjistavropoulos, H.D. Is Anxiety About Health Associated with Desire to Exercise, Physical Activity, and Exercise Dependence? Personal. Individ. Differ. 2011, 51, 1059-1062. [CrossRef]

96. Khan, M.S.R.; Putthinun, P.; Watanapongvanich, S.; Yuktadatta, P.; Uddin, M.A.; Kadoya, Y. Do Financial Literacy and Financial Education Influence Smoking Behavior in the United States? Int. J. Environ. Res. Public Health 2021, 18, 2579. [CrossRef] [PubMed]

97. Ministry of Health, Labor and Welfare. "Shintaikatudou-undou" (Physical Activity and Exercise). Available online: https: //www.mhlw.go.jp/www1/topics/kenko21_11/b2.html (accessed on 20 February 2021).

98. Nicolini, G.; Haupt, M. The Assessment of Financial Literacy: New Evidence from Europe. Int. J. Financ. Stud. 2019, 7, 54. [CrossRef]

99. Rieger, M.O. How to Measure Financial Literacy? Sustainability 2020, 13, 324. [CrossRef]

100. Huston, S.J. Measuring Financial Literacy. J. Consum. Aff. 2010, 44, 296-316. [CrossRef] 